\title{
Autonomous Writing Groups and Radical Equality: An Innovative Approach to University Writing
}

Katrin Girgensohn 1

European University Viadrina, Germany

\section{Felicitas Macgilchrist}

Georg Eckert Institute for International Textbook Studies, Braunschweig, and University of Goettingen, Germany

\section{Abstract}

This paper presents a program for a university writing group, ran as a trial in Germany, that differs from common writing groups by allowing writers a high level of autonomy and choice. To theoretically frame this writing group model, we draw on the French philosopher Jacques Rancière and his presupposition of a radical equality of intelligence. Findings suggest that the use of these writing groups provide a foundation for students to experience academic writing in ways that are more playful, creative, and joyful, without feeling inferior and increasing students' awareness of their own intelligence, capacity and creativity. By coupling grounded analysis with theoretical reflections, and a set of questions to guide practice, this paper outlines how this program could be relevant for writing educators, curriculum developers, and other faculties in higher educational institutions across global contexts.

\section{Introduction}

Imagine a set of students who receive credits for meeting weekly without teachers to improve their writing. Imagine them creating their own writing tasks, writing diverse texts during their meetings, reading and discussing them among peers. In short: imagine students working entirely autonomously, enacting an "equality of intelligence" (see below) with one another and with their teachers. Although this scenario seems unusual within the hierarchical setting of today's higher education institutions, in German speaking countries, a program based on students' autonomous writing group work has been successfully developed and implemented at several universities. 
In this paper we introduce an initiative at a German university, which focuses on the creation of student-led seminars (in the form of autonomous writing groups) within the accredited undergraduate and postgraduate curriculum. The first author developed a program that has been running for 14 years, and analyzed its implementation in an extended qualitative research study (Girgensohn, 2007). She showed that students developed creative and playful ways of enhancing their writing processes in autonomous writing groups and were able to enhance their writing competencies. The second author is an educational researcher who focuses on theories of equality and democracy, and who is interested in "thinking with theory" in qualitative research (see Jackson \& Mazzei, 2012). In reflecting together on the autonomous writing initiative, we were fascinated by the potential for (re-)thinking writing groups through the lens of Jacques Rancière's work on autonomy, democracy and equality (see Section 2). The broader goal of this rethinking is to shed light on the presuppositions underlying various writing programs, and how these presuppositions shape pedagogical practices.

In this paper, we extend Girgensohn's (2007) previous study, suggesting that the success of the program is strongly related to its implicit presupposition of an "equality of intelligence." This concept draws on Jacques Rancière's critical intervention into debates on educational practices in France in the 1980s (Rancière, 1991, see also Rancière, 1999, 2009). "Equality of intelligence" questions the role of teachers in the classroom in a radical way, where 'radical' refers to a fundamental and political rethinking of traditional roles, affirming a form of democracy which takes the signifier 'demos' seriously, and enacts equality in everyday practices, such as the design and uptake of curricula. At the same time, creating space for play and playfulness were intrinsic to the writing program (see Gee, 2004; Davies Turner \& Turner, 2015). We understand "play" here not as a trivializing element, but as an energizing means for "break[ing] through some of the constrictions that can prevent writers from achieving their best research outputs" (Badenhorst \& Guerin 2016, p. 20).

Although the questioning of teachers' roles and authority is not new in writing studies, it has proven difficult to implement changes in writing classrooms towards truly collaborative and equal learning experiences, in which teachers step away from their traditional roles within institutions of higher education as creators of writing tasks, moderators of discussions, and evaluators of students' texts. Therefore, this paper has two aims: first, we aim to present a successful initiative for developing a student-led seminar with autonomous writing groups; second, we aim to read this initiative through the lens of Rancière's radically democratic notion of equality. We present this as a theoretical framework that can aid writing instructors, curriculum designers, and other faculties across global spaces who wish to develop more 
explicitly autonomous approaches to writing facilitation. Overall, we argue that the value of this approach to writing group work is that it lays the foundations for supporting writers to write with self-efficacy and with more awareness of their own intelligence ${ }^{2}$, creativity and capacity.

To this end, Section 1 briefly summarizes debates on autonomy in the writing classroom and on writing groups. Section 2 introduces Rancière's understanding of equality, and how it relates to educational practice. Section 3 describes the seminar model in more detail, including background about students' writing in higher education in Germany, and presenting the methodology used for the previous empirical study. Section 4 reflects more explicitly on the findings, drawing on Rancière's work. Finally, in Section 5 concludes by briefly relating our findings to other forms of writing support, reflecting on the implications for writing educators, curriculum developers, and faculties in higher education institutions across global contexts, and suggesting that autonomous writing groups offer one way to enact "equality of intelligence" in the writing classroom.

\section{Autonomy in the writing classroom and writing groups}

Debates on the role of teachers and on more collaborative pedagogical approaches have a long tradition in writing studies. For example, in the 1920s and 1930s composition classrooms were expanded to writing labs, created as a way of extending the pedagogical approach of the laboratory method of instruction in the sciences to composition classrooms. Writing labs were meant as a place outside the classroom "structured to encourage self-paced learning, individualized instruction, and collaborative group work" (Murphy, 1996, p. 240, referring to Sheridan, 1926). Although very soon the misconception of writing centres as places for remedial writing support for weak writers arose, writing remained a subject that was-and is-open to innovative pedagogical approaches. Two prominent names linked with such approaches are Peter Elbow and Kenneth Bruffee, the former as an agent of expressionist writing pedagogies and the latter as an agent of social constructivist writing pedagogies.

In 1973 Peter Elbow explained why writers should learn "writing without teachers". In Elbow's view:

[The teacher] isn't really listening to you. He [sic] usually isn't in a position where he can genuinely be affected by your words. He doesn't expect your words actually to make a dent on him. He doesn't treat your words like real reading. He has to read them as an exercise. He can't hold himself ready to be affected unless he has an extremely rare, powerful openness. (Elbow, 1998, p. 127) 
Elbow describes his own experience as a struggling writer, recounting how he gained most in groups where no-one was a teacher, but everyone was a learner and reacted to his writing without being in a hierarchical position. He learned from other people who wanted to enhance their own writing and who were willing to be affected in a powerful and open way. Elbow concludes that, to develop their own voice, writers should not be disturbed by institutional constraints represented by teachers.

Another influential advocate for passing the teacher's authority to the students is Kenneth Bruffee (e.g. 1984; 1999). His ideas of collaborative learning became groundbreaking especially for writing centre pedagogies. As a result, we now have peer tutors and writing fellows in writing centres and often peer review in classrooms in most of the universities in the US (and many other countries worldwide, as Hughes and Girgensohn [forthcoming] show). In contrast to Elbow, Bruffee did not reject institutional influences. He sees a necessity for students to grow into the language of their disciplines and stresses the social character of language. In his opinion, students should construct knowledge about the use of language within their context, the university. This construction of knowledge works best among peers, argues Bruffee, because they start at the same level and have the best understanding of the challenges of this learning process, whereas teachers are too far from the level of student's knowledge to be able to construct it equally with them.

Elbow's appeal to teach and learn "writing without teachers", and Bruffee's advocacy for collaborative learning, although controversial at the time, became classics and have had a lasting impact on writing pedagogies. They represent a broad debate in writing pedagogies of the role of teachers. For example, Janet Emig (1983) introduced the idea of "magical thinking' which referred to teachers' beliefs that students learn how to write because of the teacher's teaching. The debate on shifting traditional understandings of the teacher's (authoritative) role in the writing classroom evolved to the extent that Xin Liu Gale speaks of "The New Paradigm" to refer to diverse schools of thought which "share one major assumption: that the traditional way of teaching is inadequate" (Gale, 1996, p. 12). Although the different schools disagree on the implications of teacherless writing, overall:

[C]omposition scholars and teachers [...] have come to an almost unanimous consensus that the teaching of writing cannot be done by the traditional way of lecturing $[\ldots]$ and that teaching writing has to involve a redistribution of the power that was traditionally solely the teacher's in the classroom. (Gale, 1996, p. 27-28) 
Gale's analysis of the authority of writing teachers leads her to develop the idea of "edifying teachers", that is, teachers who "strive to make their authority enabling and constructive rather than evading its existence" (157). She concludes that teachers should continue to play an important role in the writing classroom. Not, however, in the traditional way but instead by showing students "the art of communicating with others, keeping spaces open for new voices and new wonders" (157-158). Gale's perspective on the need of teachers in the classroom is related to her analysis of teachers' dependence on the institutions in which they work. She argues that teachers must become aware of the dual role they play as both enablers of critical thinking and representatives of institutions.

While Gale calls our attention to entrenched institutional power relationships, Anne Ruggles Gere reminds us to look at composition that takes place outside formal institutions, questioning the tendency in composition history to overlook writing clubs and writing groups outside of universities (Gere, 1994). She argues that we need to consider how these groups work because they often develop what we struggle to cultivate in our classrooms: a passion for writing and, for example, a "motivation to revise and improve composition skills" (Gere, 1994, p. 78). Those clubs and groups very often do not have teachers. They develop their own approach to authority, based on their own experiences. For example, in a guide for setting up writing groups, Pat Schneider suggests: "If the leader of a group stays safe, there is hierarchy" (2003, p. 191). And hierarchy, according to Schneider, compromises the members' safety and feelings of empowerment.

Gere (1987) refers to writing groups that work together without a teacher who holds the authority as "autonomous writing groups." At university, writing groups can never be truly autonomous, she argues, because a teacher will always represent the institution. She therefore refers to institutional writing groups as, at most, "semi-autonomous writing groups," and expresses doubt that they can enable one of the core experiences which members of autonomous, that is, teacherless writing groups share: "a sense of empowerment" (Gere 1987, p. 100).

These authors emphasize the constraints placed by institutions on developing autonomous and collaborative learning-to-write processes. The question that arises here is, can spaces to evade these constraints be opened if writing takes place outside the usual classroom settings? If we take up Claire Aitchison and Cally Guerin's definition of writing groups "as an umbrella generic term to refer to situations where more than two people come together to work on their writing in a sustained way, over repeated gatherings, for doing, discussing or sharing their 
writing for agreed purposes" (2014, p. 7, emphasis added), the core activities become doing, discussing and sharing writing. Sarah Haas (2014) has expanded these three activities into a complex typology of writing groups, with eleven categories and numerous sub-categories, thus highlighting the diversity of approaches to writing groups.

Although we agree with Haas that no one writing group will be the same as any other, it is nevertheless our aim in this paper to suggest that a shared set of (theoretical) presuppositions lead to writing groups operating (in practice) in certain ways. For example, observing the field of writing pedagogy in higher education, the in-meeting activities of most writing groups in university contexts focus on discussing or sharing writing. If they include the doing of writing, they often use self-directed writing, in which each student writes on their own text with the goal of getting the writing (on class assignments, dissertations, etc.) done in the motivating company of other writers. In the initiative that we present here, the main differentiating feature is that the students themselves create their own writing prompts. Their goal is to generate and collect diverse writing experiences. The group then reacts in writing to these prompts during their sessions and immediately share their texts and discuss their experiences. In this sense, they not only "do, discuss and share" writing, but they also design and shape the writing experience, a task usually reserved for teachers in positions of formalized/institutionalized authority. We will analyze the practices of these autonomous writing groups in more detail below (Section 3), after first outlining the theoretical framework and concepts with which we will read the observations on how this program unfolded in practice.

\section{Thinking with Theory: Rancière and the Equality of Intelligence}

As hinted above, this paper picks up on an ongoing discussion in educational research on how empirical research might provide insights into pedagogical practices without reducing the observable to overly simplistic models, which "tidy up" the "messiness" of social interaction, teaching and learning (Lather, 2017; Law, 2004; Adams St. Pierre, 2011). A recent intervention recommends scholars to "think with theory" as a mode of data analysis, that is, to "plug in" data to theoretical reflections and concepts to find a "language and way of thinking methodologically and philosophically together" (Jackson \& Mazzei, 2012, p. vii). The overall goal is to describe what we observe in our data as complex and multilayered, and to recall that we are observing eminently political practices. The goal of thinking with theory is also to interrogate the epistemologies and presuppositions underlying the methodologies as well as the pedagogical programs and models in the field of writing composition (see, for instance, Masny \& Cole, 2009). 
To this end, in this paper we draw on a set of concepts from Rancière's work, and "plug in" data which emerged in previous research by the first author. Our hope is that our reading of Rancière can add a fresh perspective on the question of authority, equality and autonomy in student-teacher relations in composition studies. While we do not mean to imply that the program we will describe here is the only approach to writing pedagogy which offers a useful reflection on these issues, we do hope that thinking this concrete example of a successful program will illustrate the pedagogic possibilities of Rancière's work in today's writing curricula.

When Rancière wrote The Ignorant Schoolmaster in France in the late 1980s (Rancière, 1991), it seemed to many a somewhat bizarre intervention into the educational debates of the time. The book tells the story of Jacotot; how he taught at the University of Leuven without speaking Flemish, with students who spoke no French; how he developed an unusual method of teaching in this particular situation; how he gave his students copies of a bilingual volume of Fénelon's Télémaque and had them read, recite and repeat over and over until they had finished the book; how he was astonished at their ability to write essays in French about the book. The Ignorant Schoolmaster tells of Jacotot's unusual teaching method, of his growing conviction that the teacher need not know more than the student, and of the fate of this method at the hands of institutional administrations of the time.

What relevance did the story of Joseph Jacotot, a French teacher driven into exile in Flanders in 1818, have for the daily concerns of teachers in France teaching immigrant children, or for educationalists trying to understand and counteract how the educational system reproduced social inequalities? As Kristin Ross writes in her introduction to the English translation, only a few French reviewers of Rancière's book in the late 1980s interpreted it as she invites American and British readers to read it after the legacies of Reaganism and Thatcherism (or, one could add today, in the Trump era): "as an essay, or perhaps a fable or parable, that enacts an extraordinary philosophical meditation on equality" (Rancière, 1991, p. ix). Indeed, the radical understanding of equality that Rancière formulates in this book can be seen as one of the defining features of his (political) theory which he developed further in later work (see, for example, Rancière 1991, 1999, 2007).

We see the following three aspects of Rancière's intervention into educational debates as particularly relevant to writing pedagogy: (i) the current governing presupposition of intellectual inequality and the role of explanation in enacting this stultifying presupposition, (ii) the difference between emancipation as transmitting knowledge and emancipation as driving the will, and (iii) the practical verification of the presupposition of intellectual equality. 


\section{Intellectual (in)equality}

It seems almost a common-sense assertion to state that current educational systems across the globe reproduce social inequalities. A common conclusion drawn by educationalists is thus that "those who know," that is, teachers or sociologists, must do something to educate and emancipate "those who do not know," that is, students or students' parents. Rancière's strongest intervention into this self-evident conclusion is to reflect on the logic of the pedagogical relationship. The very aim to reduce the distance between teacher and student is, he suggests, what constructs a distance and a hierarchy between the two. The teacher creates lessons (readings, tasks, assignments) to reduce the gulf between her knowledge and the ignorance of the student. To do this, she must, however, always remain one step ahead of the student. Why?

The reason is simple, according to Rancière: in a pedagogical logic, the "ignoramus" (he uses the word ironically) is not simply someone who does not yet know what the schoolmaster (sic) knows-she is the one who does not know what she does not know and does not know how to begin to know it. For his part, the schoolmaster is not only the one who possesses the knowledge unknown by the allegedly ignorant learner. He is also the one who knows that he knows it; he knows how to make it an object of knowledge, at what point and in accordance with what protocol (see Rancière, 2007, p. 8).

The teacher, in other words, is thought to have the methodological competence to create structured lessons in accordance with particular curricula. The teacher-or the policy, curriculum or writing program-decides in what order which content and which competencies are to be addressed; they decide which learning outcomes are appropriate for this particular stage in the learning process. This chunking of the learning process into "appropriate" phases of increasing difficulty, presupposes and recreates a gulf between the-teacher-who-knows and the student-who-does-not-know. In this logic, the student will in fact never reach the knowledge of the teacher. The teacher will always remain one step ahead on the ladder of knowledge. The "pedagogical myth [...] divides intelligence into two. It says that there is an inferior intelligence and a superior one" (Rancière, 1991, p. 7). Rancière's critique is not, we suggest, quite the same argument as the more established critique of teacher authority in the classroom. It adds the performative dimension that even well-intentioned critical educationalists who are trying to reduce the gulf in power/authority also, by presupposing that this gulf exists (rather than assuming there is no gulf in power/authority), themselves (inadvertently) recreate something which counts as an inferior and a superior intelligence. 
In Rancière's tale, Jacotot's experience in Flanders showed him that his students learned French and could engage with the Télémaque perfectly well without his superior intelligence explaining to them how the language was structured or what the book was about. He began to question the necessity of explanation in educational practice. The pedagogical logic assumes that teachers must explain to students how language, math, academic writing, chemistry, etc. work. Teachers scaffold students' learning with their explanations. Jacotot's new insight was that this assumption had to be overturned.

Rancière argues strongly against the expectation that explanation can help to remedy an apparent incapacity to understand. He questions the very assumption on which this expectation rests, arguing that the idea of anyone 'lacking understanding' is a fiction. Learners do not per se lack understanding. Instead, teachers who aim to explain require listeners who are addressed as lacking; a teacher who explains performatively constitutes their student-listener as lacking understanding. The act of explaining something constructs listeners as people who cannot work it out by themselves (see Rancière 1991, p. 6).

No matter how well-meaning the intentions of the explainer, the act of explaining presupposes that the explainer knows more than the listener. It addresses the student as a person who is incapable of understanding, as a person who needs the help of the teacher's superior intelligence. This in turn has a "stultifying" effect on the student: "What stultifies the common people is not the lack of instruction, but the belief in the inferiority of their intelligence" (Rancière 1991, p. 39). We pick up Rancière's work in practice to ask ourselves (as curriculum designers, policy-makers, or instructors) a set of guiding questions: Am I using the act of explaining to students? If so, how am I addressing them as I am explaining to them? Is it possible to explain anything without positioning myself as the "knower" and my listeners as "nonknowers"? Is this position likely to help or hinder their learning and their feelings of competence? Are there any alternatives open to me in this situation (rather than explaining)?

\section{Verification}

The above description may prompt two questions; first, is Rancière suggesting that everyone is capable of doing complex long division in their head or writing A+ assignments? Second, is the teacher completely redundant in this view of education which avoids explanation? We will return to the second question below. First, if we presuppose the equality of intelligence (among teachers, students, etc.) as Rancière suggests, do we also assume that everyone can, for instance, achieve the same academic success? Rancière is quite clear that "everyone is of equal intelligence" (1991, p. 101). Although there is "inequality in the manifestations of intelligence", 
there is "no hierarchy of intellectual capacity" and there "aren't two sorts of minds" (27). The same intelligence is at work in the child learning her first words as in the illiterate person learning to read as in the scientist constructing hypotheses: "an intelligence that translates signs into other signs and proceeds by comparisons and illustrations in order to communicate its intellectual adventures and understand what another intelligence is endeavouring to communicate to it" (Rancière 2009, 10). The child, the illiterate person, the scientist: each "observes, selects, compares, interprets" (13).

"Verification" is the name Rancière gives to practices which enact this presupposition of equality. Verification is at the same time, lived democracy. Rather than seeing equality as a goal to be achieved, and acting to achieve this goal, what happens if we presuppose the equality of all living beings now-taking it as our point of departure-and act to verify this presupposition (see Rancière, 1991, p. 138)? The revolutionary political actions during the Occupy movement, the Arab Spring, or the Black Lives Matter protests enacted the presupposition that "yes, we already can," rather than "one day we will be able to" (see Citton, 2010, p. 32). Equality is not "given" by those more knowledgeable or those in power; it is practiced, it is verified (see Rancière, 1991, p. 33; Norval, 2009). The equality of intelligence cannot be shown. IQ tests will always be able to identify hierarchies. The value of the presupposition lies instead in its effects in daily (political/educational) practice. Again here, we think with Rancière about verification to interrogate our own practices. A guiding question for faculty and other instructors or curriculum developers could be: are these practices verifying an equality of intelligence (among teachers, students and other students), in which each of us observes, selects, compares, and interprets?

\section{Knowledge and will}

This question recalls the issue above: is the teacher still necessary in this kind of education which presupposes equality among all, and which negates the need for explanations? In Rancière's story, Jacotot was not dispensable. Rancière distinguishes between the teacher transmitting knowledge to students, and the teacher's driving of the students' will (1991, p. 68). The students did learn from Jacotot: he told them to look, to pay attention, to repeat, to imitate, to translate, to take apart, to put back together again (68). He did not transmit any knowledge to them, but instead enabled them to engage with the language and content of the Télémaque.

This critique of teaching as knowledge transmission is familiar when one thinks of Rousseau, Dewey, Freire and critical pedagogy. Progressive educationalists have long rejected the idea of the learner as tabula rasa and the "banking" model of education, in which the teacher fills the empty vessel of the learner with knowledge. These have been replaced by concepts of the active 
Volume 28, 2018

http://journals.sfu.ca/cjsdw

learner and the student as co-creator of knowledge. For Freire (1993), for instance, a particular teaching methodology-problem-posing-is implemented by the teacher and helps to lead the student from a state of oppression to a state of emancipation. For Charles Bingham and Gert Biesta (2010), the core difference between Freire's Pedagogy of the Oppressed and Rancière's Ignorant Schoolmaster lies in the figure of the child: Freire holds onto a psychological concept of the child which "assumes a developmental telos," i.e. ideas of how to bring the child from one position of oppression to another position of emancipation; "this is exactly the sort of telos that Rancière is at pains to eschew" (63).

We see far more similarities in the work of Freire and Rancière than Binghman and Biesta are willing to concede. The key difference we read is the simplicity and explicitness with which Rancière names the presupposition of equality. Freire insists that problem-posing education "breaks with the vertical patterns characteristic of banking education" (Freire 1970, 1993, p. 61), that teacher and student "become jointly responsible for a process in which all grow" (61), and that "no one teaches another, nor is anyone self-taught" (61). Nevertheless, individuals implementing problem-posing education could still assume from Freire's account that the teacher (teacher-student) knows more than the students (students-teachers). Our third set of guiding questions which draw from thinking with Rancière is thus: what happens to our pedagogical practice if we check for all our actions; are we really acting on the assumption that the role of the teacher and/or the curriculum is to drive the students' will (or in a more recent formulation: to facilitate and enable students), rather than to pass on knowledge?

\section{Implementing a Program for Autonomous Writing Groups}

Before asking how "thinking with" Rancière's approach to radical equality in educational practice can help us analyze and reflect on the autonomous writing groups, in this section, we first briefly describe the context of writing at universities in Germany. We then turn to a more detailed account of the writing program as it was developed and implemented at a German university, and to the initial study of its implementation.

\section{University Writing in Germany}

Like many European universities, German universities rarely provide explicit writing support, so writing skills tend to be "acquired by immersion" (Breuer \& Schindler, 2016, p. 94). David Foster shows that faculty at German universities see themselves as teachers of their subject, not as writing teachers (Foster, 2002, p. 192). In fact, with no composition classes and with teachers 
not regarding themselves as writing teachers, students have few opportunities to raise their awareness of writing processes.

One reason for the lack of explicit writing support is the tripartite system of schooling in Germany, in which students are streamed by ability at a relatively young age. Students who are seen as capable of going on into higher education attend a selective (academic) school called the "Gymnasium." University teachers tend, therefore, to assume that these students are schooled in argumentative writing. At university, students immediately study within their degree disciplines and often write extended research papers (approx. 20 pages) according to the rules of the discipline from the first semester. Macgilchrist and Girgensohn (2011) show how challenging these research papers can be, given the lack of explicit writing guidance for students. Due to the preponderance of these extended papers, and the relative lack of short essays or other introductory genres, our observation is that the distinction between undergraduate and graduate writing is less marked than it is in other parts of the world, for instance, in North America. Both undergraduates and graduate students must figure out the implicit rules, norms and values of their disciplines in a relatively independent manner.

Only recently have universities in Germany started to offer writing support. This support is generally linked to writing centres, which are also a recent development in Germany (Macgilchrist \& Girgensohn, 2011; Hughes \& Girgensohn, forthcoming). Although this development is striking, and German writing centres are among the fastest growing worldwide (Scott, 2016, 2017), it remains quite rare for students to have the opportunity to attend writing classes. The concept of autonomous writing groups that we introduce here must be regarded in this context. It was developed neither as a part of composition classes nor as an alternative to composition classes, but as an opportunity for students to explore writing in a context with rare explicit writing instruction. The program was originally developed in 2003 at the EuropeanUniversity Viadrina, a public university that was re-opened after the inner-German wall came down and explicitly aims to foster innovative ways of learning. The absence of a tradition of writing instruction including a lack of debate among German-speaking scholars about writing instruction led to an unusual freedom in being able to design this class. Nevertheless, given the current negotiations around potential future programs and models for the 21st century (Partnership for 21st Century Skills, 2015), alongside a sense of urgency among progressive educators that today's political context requires us to rethink the role of autonomy, democracy and equality in pedagogical practice (Giroux, 2017), perhaps now is a particularly ripe time for exploring this type of program in a range of contexts around the world. 
Volume 28, 2018

http://journals.sfu.ca/cjsdw

\section{The autonomous writing initiative: "Let's Write!"}

The initiative with the title "Let's Write!" was designed as a seminar, being part of the curriculum across several degree programs at the Faculty of Cultural Sciences at the EuropeanUniversity Viadrina. It can be chosen by undergraduate students as well as by graduate students taking courses for credit. An extended study of this seminar, using a grounded theory approach based on interviews, group discussions, text analysis and ethnographic observations, published in 2007 (Girgensohn, 2007, see below), led to the adoption of the program at several other universities in German speaking countries. In this section, we explain the format of the initiative's seminar model.

The seminar offers places for up to 30 students. It starts with a kick-off-weekend outside the university, where students start to explore writing and choose their writing groups. After this weekend, the writing groups meet autonomously every week throughout the semester. Students alternately prepare their group meetings, including designing the writing tasks. At the end of the semester, the students come together to celebrate their texts in a public reading. Each group hands in a collection of self-selected texts to get credit for the class, but the texts are not graded.

The kick-off weekend is crucial for the success of the seminar. For three days, the whole group, together with a teacher, travels to a residential training centre. Students report that it is key to their learning that their groups form a community. To accomplish this, it is very important that the groups are self-selected. This choice is only possible because students have the opportunity to get to know each other during the weekend. Furthermore, it is essential that the students take responsibility and that they act in a non-hierarchical way. The kick-offweekend lays the ground for this by making the participants familiar with the roles they will play in this seminar (Girgensohn, 2007, p. 144-163).

The role of the teacher in this setting is that of a facilitator who shows the students opportunities, provides a learning environment, and sets the mood. Therefore, in the beginning, the teacher gives the students an introduction to the idea and purpose of the seminar, which, in summary, is:

- to enable students to write regularly;

- to offer encouragement for writing;

- to help students to explore different ways, strategies, and methods of writing;

- to make students aware of their own writing processes;

- to encourage them to share their writing in progress; 
- to give them an audience for their writing;

- to delegate the responsibility of the learning process to the students themselves;

- and to give the teacher the chance to teach up to 30 students effectively, despite the budget of only 90 minutes a week. (Bräuer \& Girgensohn, 2012, p. 233)

The teacher, in a brief presentation, also introduces some findings from writing research to orient students to the background of developing this seminar concept. Thus, students get an idea of the seminar's pedagogical approach and how it is based on research findings. However, the presentation's primary aim is to share a map of the current landscape, rather than to pass on knowledge about composition as content to be learned by the students.

The role of the students during the kick-off-weekend is to explore writing and discover their own preferences and styles. Most of the time is dedicated to offering students intensive writing experiences. They work with writing tasks that were developed based on research by Hanspeter Ortner (2000), who argues that writing processes are highly individual and that it is therefore not possible to provide learners with one successful model for writing well. Drawing on statements by professional creative writers, Ortner identified ten different strategies that professional writers use to write their texts. Following a suggestion by Ingrid Böttcher and Cornelia Czapla (2002), these ten strategies were translated into ten different writing tasks for the kick-off weekend. For example, writers create a text without planning in advance, or they should write different parts of a text in a random order, as indicated by rolling dice. The students choose different tasks and decide how much time they will dedicate to each task. Small groups come together several times throughout the weekend to discuss their experiences and the texts they have written.

By meeting in different groups and through the social surroundings, such as cooking together and sharing rooms and meals, the participants get to know each other quite well. This is an important precondition for the group-finding process that takes place on the third day of the weekend. Students reflect on their preferences for the upcoming writing group with regard to the genres and styles they wish to explore, but also regarding the type of group experience they wish to have and their personal expectations and anxieties. It is a long and sometimes painful process for the students to find their partners. For a teacher used to traditional methods, it might be not easy to stand aside and to avoid "helpful" suggestions.

After the weekend trip, students and teachers maintain these roles. Each group of students meets once a week. Students take turns as the moderator for a designated week. Moderators 
choose a theme and assignments and explore different ways of staging their writing group meeting, which always includes writing.

The teacher stays in the background and is available during office hours to discuss students' plans for the group meetings. After their meeting, the moderators reflect on their ideas and plans, on the meeting, and on the outcomes in written proceedings (minutes) that they send the teacher within one week. The teacher acts as an interested reader, sharing thoughts, questions and ideas on these minutes.

At the end of the semester, all the small groups come together for a shared public reading. Afterwards, each group hands in a collective portfolio with a selection of texts that were written during the semester. Although the institution requires formal assessment (grades), the assessment in this initiative does not focus on the quality of writing. Instead, since students were requested to be creative and experimental and because their audience was their groups and not the teacher, grades are based on the involvement of students and on the extent of their reflections on their proceedings.

The autonomous writing group initiative has now been running for 14 years at the European University Viadrina, and has been successfully implemented in several other universities. The following impressions can be summarized:

- Enthusiasm: Most groups remain together as a unit throughout the semester, working together in a continuously enthusiastic way. The weekly sessions are generally, at least, three hours long. To meet for such extended periods of time was the participant's' own decision. In this time, the groups wrote many texts.

- Awareness: In the groups, a sophisticated awareness of writing processes developed. Students discussed a range of different strategies, styles and genres. They described this in the minutes they wrote after each session, and in face-to-face discussions during office hours. Students adopted the responsibility and authority of managing the weekly sessions. They explored new ways of running the sessions, and in office hours they asked for new and different strategies of writing. We (the two authors) have never experienced this active practice of equal responsibility and authority in "standard" university classes.

- Novelty and Play: Students surprised teachers with the range of novel ideas they implemented in their writing group work. The genres and issues they thought of, which had never occurred to the teachers involved, enacted an equality of intelligence which was inspiring to see. Students wrote poems, stories, speeches, journal articles, soap operas, criminal stories and fairy tales. They wrote about German-Polish relationships, death, Christmas, ways of living, love and sex. They wrote in the underground, in a cemetery, in 
bars, hotels and museums. They also gained experiences with writing academic papers, finding arguments, finding an appropriate style, etc. In one group, students wanted to practice a form of academic writing and presenting. They wanted to avoid a boring meeting, however, so they planned a mock conference. They wrote formal invitations to the other members, calling them Dear Professor X or Dear Doctor Y and asking them to come in formal dress to the lobby of one of the grandest hotels in Berlin. They sent nametags with this invitation, with a logo they created especially for this meeting. On the designated day, the moderators held a formal speech in the hotel lobby and presented a list of sub-themes to choose from. These all referred to one central theme: why do young people have changing relationships; what different names for having sex exist, how are they used, and what does this mean for our society; what do we know about having sex with kitchen utensils, etc. Participants had 40 minutes to prepare their papers. They reported that presentations were held in a serious academic style and they reported enjoying both the writing and the listening (see Girgensohn, 2006).

- Output: Groups were requested to submit a simple folder containing the texts they had written during the semester. Instead, they handed in beautiful compilations of texts, compiled and designed with great care. The students reported that this collection was a souvenir for them, something to remind them of a valuable period of their life.

- Importance: Participants reported that the writing group was home for them; they compared it to an oasis in the university. It seems that the writing groups meant more to the students than a regular university class. The writing group work helped them to express themselves, which led to very close relationships. They felt secure amongst equal peers and without a teacher immediately judging their development in writing from a position of superiority or authority.

\section{Autonomous writing groups and the social factor}

The development and implementation in the first three semesters of this autonomous writing group program were accompanied by a study by Girgensohn (2007). The study used a grounded theory approach, collecting data in iterative procedures. The overall research questions that had been developed during this process asked: "What, from the perspective of student writers, is important for the writing group work and the development of writing competences? What hinders and what supports their development as writers?" (Girgensohn, 2007, p. 127). The database consists primarily of ten problem-oriented interviews (Witzel, 2000), four group discussions (Girtler, 2001) and additionally: numerous minutes from writing group sessions 
written by the students; various students' texts; audio-recorded counseling sessions; field notes and other documents. Every piece of data used for the study has the permission of the student writers. For the analysis, Girgensohn followed the procedures of open, axial, and selective coding supported by extensive memo-writing that Strauss and Corbin (1990) suggest. The development of findings was discussed within a collaborative research group and the data analysis was managed using the software Maxqda. The research process lasted four years, culminating in a book published in 2007.

The results show how important it is for the student writers that their groups develop what one of them called "the social factor." Participants stressed the need to develop trust and a feeling of community. This supports other available findings (e.g. Guerin, 2014; Thesen, 2014). However, as Aitchinson and Guerin $(2014$, p. 7) state, there is no guarantee that writing groups will be successful, they can also lead to frustrating experiences for writers.

In the original study of the implementation of the program, Girgensohn (2007) identified the "social factor" as a central element in the perceived success of the program for students. The selection of group members played a salient role, as did the self-reliance, and feeling of being on an equal footing with other participants in their group. In the writing groups that were able to develop the social factor, writers experienced writing in different functions. Not only as a way to express knowledge (rhetorical function), but also as a way to bond and communicate (communicative function); develop personality (personal function); develop ideas (heuristic function), and experience joy (hedonistic function). The study indicates that it is the very interplay of these functions which leads student writers to experience writing with less feelings of inferiority, to develop self-efficacy in writing, and to develop creativity. Overall, it can be said that this interplay of functions enhances the sustainable development of writing competences. Thus, a reduction of writing experiences at university to the rhetorical or "transactional function," as Britton and others (1975) call it, might be a reason for the problems reported by many writers, such as anxiety, postponement, and reluctance. Graduate writers especially need to be able to develop ideas and creativity independently and with self-confidence (Gardner 2008).

\section{Thinking autonomous writing groups with Rancière}

Autonomous writing groups like the initiative presented here seem to be able to lay the groundwork for just this kind of playful, creative, self-reliant, multi-functional writing which is experienced as successful and meaningful. However, in reflecting on the program several years later, and, as noted above, while "thinking with theory," we realized this groundwork relies on a 
set of presuppositions, which Rancière help us to elucidate. Drawing on Rancière's story of the teacher Jacotot (see above), we see the writer and writing teachers (or supervisors) interacting in this writing initiative according to three principles: (1) All participants must take the idea of autonomy seriously. (2) The teacher must adopt a particular role, driving the will of the participants. (3) The teacher must presuppose (and thus verify) the equality of intelligence.

First, teacher and students must take the idea of an autonomous writing group seriously. The teacher does not attempt to pass on knowledge at any stage. As noted above, groups are selfselected; moderators choose the themes and methods they are interested in exploring. Participants do not submit their writing output to the teacher for assessment. Students' practices in planning, organizing and running the weekly sessions place them in equal positions of authority and responsibility, not only with one another, but also with the "official" (institutional) teacher-figure.

Second, the role of the teacher changes: she is no longer the one who is responsible for students' learning processes. Instead, she drives their will, as evidenced in the facilitating role she plays in the kick-off weekend. Like Jacotot, she offers them opportunities to experiment with and reflect on writing processes which, since they have signed up for the class, they cannot avoid. She offers them resources to prepare the weekly meetings. To assist these preparations, the teacher makes available, e.g. in the library, a variety of useful books and other materials. The teacher also suggests methods that groups can try during the semester, like clustering, freewriting, writing different versions of one text and some forms of peer reviewing.

Third, the teacher acts towards the students on the presupposition of equality of intelligence. At the kick-off weekend, students explore different strategies themselves. The teacher does not explain things to them, which would assume a gulf in understanding or intelligence which needs to be bridged by explanation. The ten tables are set up in advance, and students make their way around the stations as they see fit. The students write a lot of texts during this time. Texts are read and discussed in small groups. Again, at no point does the teacher explain their knowledge to the students. Although they give a brief overview of writing research at the beginning, this overview is not meant to pass on knowledge, but to present the teacher as a member of the group, and to tell (narrate to) the students their motivations for designing this very special seminar form. For the first moment, students begin to talk about how they write. They develop confidence in their ability to write. As we noted above, according to Rancière, what "stultifies" students are, primarily, "the belief in the inferiority of their intelligence" (Rancière, 1991, p. 39). This is one belief that the seminar design tries to overcome. 
http://journals.sfu.ca/cjsdw

This third aspect is perhaps the core aspect: Some observers may even say that if a teacher acts on the presupposition of equality, it is less important which specific methods and approaches are employed in the class. This freedom from specific methods or pedagogies, makes the program, in our view, particularly adaptable to different national or institutional contexts. The core focus is on teachers no longer "explaining;" instead, the emphasis lies in their role in "telling," "narrating," "eliciting," and "motivating." The very supposition on which teachers and students then enact their social relationships breaks with traditional institutional relations of superiority and inferiority. This presupposition can be "operationalized" in very different institutional forms, one of which we have recounted in this paper. This presupposition has the potential to institute a form of radical equality, which could potentially be transposed across further sections of contemporary society.

\section{Conclusion}

In this paper, we have introduced Rancière's notion of equality as a theoretical framework that can help teachers, and especially writing teachers, to argue for more radical autonomous approaches for writing facilitation. We outlined a successful initiative, undergirded by a grounded analysis of practice and reported outcomes, which illustrates how Rancière's work can be intertwined with writing pedagogies by introducing the concept of a student-led seminar with autonomous writing groups.

The theoretical framework suggests that one central aspect to the organization, teaching, and learning of the autonomous writing groups is a particular assumption underlying the social interaction: the presupposition of a radically democratic sense of "active equality" (May, 2008, p. 2). One core assumption of the approach is that "explanation" runs counter to equality. As noted in the introduction, we are not suggesting that this form of student-led seminar is the only approach to writing pedagogy which verifies this presupposition of equality. However, we do hope that this concrete example of verification-in-action serves to illustrate the pedagogic possibilities of Rancière's thought for developing writing curricula in a diversity of institutional contexts today. We outlined a series of questions which writing instructors, writing centre managers, other faculty and curriculum developers (across global contexts) may find helpful in designing and enacting writing programs and classroom practices.

Of course, the autonomous writing group itself might not be enough for students to learn to perform successful academic discourse or to question entrenched power relations in society. We are also not suggesting that they should replace other graduate writing group models that focus more on the sharing of dissertation texts, and giving feedback on one another's texts. However, 
http://journals.sfu.ca/cjsdw

the autonomous writing groups as presented here can lay the groundwork for students in institutions of higher education to experience writing with fewer feelings of inferiority and with more verification and awareness of their own intelligence, capacity, and creativity. The presuppositions which undergird the program presented here can be explicitly enacted while developing and/or implementing programs tailored to specific institutions.

\section{Endnotes}

1. Correspondence may be addressed to girgensohn@europa-uni.de

2. As the second section in this paper will describe in more detail, we do not refer to "intelligence" here in the psychological sense of a testable intelligence quotient, nor to theories of emotional intelligence or multiple intelligences, each of which assume that some individuals are "more capable" in certain spheres and others are "less capable" Instead, we draw on Jacque Rancière's quite unusual take, in which IQ scores are only different "manifestations" of intelligence (Rancière 1991, p. 27). Intelligence itself, on the other hand, is something we all share: Each of us "observes, selects, compares, interprets" (Rancière 2009, p. 13), and each of us, in this sense, is equally capable of observing, selecting, comparing and interpreting.

\section{References}

Adams St. Pierre, E. (2011). Post Qualitative Research: The Critique and the Coming After. In N.

K. Denzin \& Y. S. Lincoln (Eds.), The SAGE Handbook of Qualitative Research (pp. 611-626).

Thousand Oaks: Sage. DOI: 10.1177/1077800417734567

Aitchison, C., \& Guerin, C. (2014). Writing groups, pedagogy, theory and practice: An introduction. In C. Aitchison \& C. Guerin (Eds.), Writing groups for doctoral education and beyond. Innovations in practice and theory (1st ed., pp. 3-17). London, New York: Routledge. DOI: $10.1163 / 9789004304338 \_002$

Badenhorst, C., \& Guerin, C. (Eds.). (2016). Research Literacies and Writing Pedagogies for Masters and Doctoral Writers. Leiden, NL: Brill.

Bingham, C., \& Biesta, G. (2010). Jacques Rancière: Education, truth, emancipation. London: Continuum.

Böttcher, I., \& Czapla, C. (1995). Repertoires flexibilisieren: Kreative Methoden für professionelles Schreiben. In J. Baurmann \& R. Weingarten (Eds.), Schreiben: Prozesse, Prozeduren und Produkte (pp. 182-201). Opladen: Springer. 
Bräuer, G., \& Girgensohn, K. (2012). Literacy Development Projects Initiating Institutional Change. In C. Thaiss, G. Bräuer, P. Carino, L. Ganobcsik-Williams, \& A. Sinha (Eds.), Writing Programs Worldwide: Profiles of Academic Writing in Many Places (pp. 225-238). Anderson, SC: Parlor Press and the WAC clearinghouse.

Britton, J., Burgess, T., Martin, N., McLeod, A., \& Rosen, H. (1975). The Development of Writing Abilities. London: Macmillan.

Breuer, E. O., \& Schindler, K. (2016). Germany. In O. Kruse, M. Chitez, B. Rodriguez, \& M. Castello (Eds.), Exploring European Writing Cultures. Country Reports on Genres, Writing Practices and Languages Used in European Higher Education. Working Papers in Applied Linguistics: Vol. 10. (pp. 87-100). Zürich. DOI: 10.21256/zhaw-1056

Bruffee, K. A. (1984). Peer Tutoring and the 'conservation of mankind'. College English, 46(7), 635-652.

Bruffee, K. A. (1999). Collaborative learning: Higher education, interdependence, and the authority of knowledge. Baltimore, MD: John Hopkins University Press.

Citton, Y. (2010). "The ignorant schoolmaster": Knowledge and authority. In J.-P. Deranty (Ed.), Jacques Rancière: Key Concepts (pp. 25-37). London: Acumen.

Davies Turner, M., \& Turner, J. (2015). Play and creativity in academic writing. In C. Badenhorst \& C. Guerin (Eds.), Research Literacies and Writing Pedagogies for Masters and Doctoral Writers (pp. 356-370). Leiden, NL: Brill.

Elbow, P. (1998). Writing without Teachers. New York, Oxford: Oxford University Press.

Emig, J. (1983). Non-Magical Thinking: Presenting Writing Developmentally in Schools. In J. Emig (Ed.), The Web of Meaning. Essays on Writing, Teaching, Learning and Thinking (pp. 132-144). Portsmouth: Boynton/Cook Publishers.

Foster, D. (2002). Making the Transition to University: Student Writers in Germany. In D. Foster \& D. R. Russel (Eds.), Writing and learning in cross-national perspective (clone) -Transitions from secondary to higher education (pp. 192-241). Urbana, Ill: National Council of Teachers of English.

Freire, P. (1993). The Pedagogy of the Oppressed. London: Penguin.

Gale, X. L. (1996). Teachers, discourses, and authority in the postmodern composition classroom. Albany: State University of New York Press. Retrieved from http://www.gbv.de/dms/bowker/toc/9780791427651.pdf

Gardner, S. K. (2008). "What's too much and what's too little?": The process of becoming an independent researcher in doctoral education. The Journal of Higher Education, 79(3), 326350. DOI: $10.1353 /$ jhe.0.0007 
Volume 28, 2018

http://journals.sfu.ca/cjsdw

Gee, J. P. (2004). Situated language and learning: A critique of traditional schooling. London: Routledge.

Gere, A. R. (1987). Writing groups: History, theory and implications. Carbondale and Edwardsville: Southern Illinois Press.

Gere, A. R. (1994). Kitchen tables and rented rooms: The extracurriculum of composition. College Composition and Communication, 45(1), 75-92. DOI: 10.2307/358588

Girgensohn, K. (2006). How to make a virtue out of necessity: Teacherless writing group work at the European University Viadrina/Germany. In European Association for the Teaching of Academic Writing (Ed.), EATAW Athens Conference Proceedings. Athen: Hellenic American Union.

Giroux, H. A. (2017). The public in peril: Trump and the menace of American authoritarianism. New York: Routledge

Guerin, C. (2014). The gift of writing groups: Critique, community and confidence. In C. Aitchison \& C. Guerin (Eds.), Writing groups for doctoral education and beyond. Innovations in practice and theory (1st ed., pp. 128-141). London, New York: Routledge.

Haas, S. (2014). Pick-n-mix: A typology of writers' groups in use. In C. Aitchison \& C. Guerin (Eds.), Writing groups for doctoral education and beyond. Innovations in practice and theory (pp. 30-47). London, New York: Routledge.

Hughes, B., \& Girgensohn, K. (forthcoming). Ideas flowing widely - Writing centers from an international perspective. In C. Bazerman (Series Ed.) \& M. A. Pemberton \& K. Dvorak (Vol. Eds.), Reference Guides to Composition Studies. Writing Centers. Fort Collins, CO: WAC Clearinghouse.

Jackson, A. Y., \& Mazzei, L. A. (2012). Thinking with theory in qualitative research: viewing data across multiple perspectives. London: Routledge.

Lather, P. (2017). (Post)critical methodologies. The science possible after the critiques. London: Routledge.

Law, J. (2004). After method: Mess in social science research. London: Routledge.

Macgilchrist, F., \& Girgensohn, K. (2011). Humboldt meets Bologna: Developments and debates in institutional writing support in Germany. Canadian Journal for the Study of Discourse and Writing, 23(1). Retrieved from http://journals.sfu.ca/cjsdw/index.php/cjsdw/article/view/556

Masny, D., \& Cole, D. R. (2009). Multiple literacies theory: A Deleuzian perspective. Rotterdam: Sense. 
Volume 28, 2018

http://journals.sfu.ca/cjsdw

May, T. (2008). The political thought of Jacques Rancière: Creating equality. Edinburgh:

Edinburgh University Press.

Murphy, C. (1996). Writing centers. In P. Heilker \& P. Vandenberg (Eds.), Keywords in Composition Studies (pp. 240-243). Portsmouth: Boynton/Cook.

Norval, A. (2009). Democracy, pluralization and voice. Ethics \& Global Politics. (2), 297-320.

Retrieved from

http://www.ethicsandglobalpolitics.net/index.php/egp/article/view/2118/3932.

Ortner, H. (2000). Schreiben und Denken. Reihe germanistische Linguistik: Vol. 214. Tübingen:

Niemeyer.

Girgensohn, K. (2006). How to Make a Virtue out of Necessity: Teacherless Writing Group Work at the European University Viadrina/Germany. In European Association for the Teaching of Academic Writing (Ed.), EATAW Athens Conference Proceedings. Athen: Hellenic American Union.

Girgensohn, K. (2007). Neue Wege zur Schlüsselqualifikation Schreiben: Autonome Schreibgruppen an der Hochschule. Wiesbaden: VS Research.

Partnership for 21st Century Learning. (2015). P21 Framework definitions. Retrieved 17 October 2017 from http://www.p21.org/our-work/p21-framework.

Rancière, J. (1991). The ignorant schoolmaster: Five lessons in intellectual emancipation. Stanford, CA: Stanford University Press.

Rancière, J. (1999). Disagreement: Politics and philosophy. Minneapolis: University of Minnesota Press.

Rancière, J. (2007). On the shores of politics. London: Verso.

Rancière, J. (2009). The emancipated spectator. London: Verso.

Schneider, P. (2003). Writing alone and with others. Oxford: Oxford Univ. Press.

Scott, A. (2016). Re-centering writing center studies: What U.S.-based scholars can learn from their colleagues in Germany, Switzerland, and Austria. Zeitschrift Schreiben. (28.11.2016), 110. Retrieved from https://zeitschrift-schreiben.eu/globalassets/zeitschriftschreiben.eu/2016/scott_writingcenterstudies.pdf

Scott, A. (2017). 'We would be well advised to agree on our own basic principles': Schreiben as an agent of discipline-building in writing studies in Germany, Switzerland, Austria, and Liechtenstein. Journal of Academic Writing, 7(1), 43-58. DOI: 10.18552/joaw.v7i1.219

Sheridan, M. C. (1926). An evaluation of the Dalton Plan. English Journal, 15(7), 507-514.

Strauss, A., \& Corbin, J. (1990). Basics of qualitative research: Grounded theory procedures and techniques: Sage Publications. 
Volume 28, 2018

http://journals.sfu.ca/cjsdw

Thesen, L. (2014). 'If they're not laughing, watch out!': emotion and risk in postgraduate writers' circles. In C. Aitchison \& C. Guerin (Eds.), Writing groups for doctoral education and beyond. Innovations in practice and theory (1st ed., pp. 145-176) London, New York: Routledge.

Witzel, A. (2000). Das problemzentrierte Interview. Forum Qualitative Sozialforschung/ Forum Qualitative Research (Online Journal). (1), 26 Absätze. Retrieved from http://nbnresolving.de/urn:nbn:de:0114-fqs0001228. 